\title{
Pengaruh Pembangunan Ruas Jalan dan Jembatan Cenrana - Labotto Terhadap Perekonomian Masyarakat
}

\section{Studi Kasus: Kecamatan Cenrana Kabuaten Bone}

\author{
The Effect of Cenrana - Labotto Roads and Bridges Construction on The Economy of Community \\ Case Study: Cenrana Village, Bone Regency \\ Muhammad Khomeini ${ }^{1}$, Murshal Manaf ${ }^{2}$, Agus Salim $^{2}$ \\ ${ }^{1}$ Dinas Pekerjaan Umum Kabupaten Bone \\ ${ }^{2}$ Porgram Studi Perencanaan Wilayah dan Kota, Program Pascasarjana Universitas Bosowa \\ Email: khomeinirusdi@gmail.com
}

Diterima 17 November 2019 / Disetujui 20 Maret 2020

\begin{abstract}
Abstrak. Tujuan dari penelitian ini adalah untuk mengetahui pengaruh pembangunan ruas jalan dan jembatan Cenrana-Labotto terhadap perkembangan perekonomian masyarakat di Kecamatan Cenrana. Dianalisis menggunakan metode regresi linear berganda yang dibantu dengan software SPSS 22.0 untuk mengetahui pengaruh faktor pertumbuhan penduduk, pertumbuhan perdagangan, infrastruktur transportasi, dan pertumbuhan teknologi transportasi terhadap peningkatan ekonomi masyarakat. Hasil analisis disimpulkan bahwa faktor-faktor yang berpengaruh signifikan pada ruas jalan dan jembatan Cenrana-Labotto terhadap peningkatan perekonomian masyarakat Kecamatan Cenrana yaitu faktor perubahan struktur ekonomi masyarakat, meningkatnya harga lahan, serta pertumbuhan penduduk yang berpengaruh signifikan dan cukup kuat, pertumbuhan perdagangan berpengaruh signifikan namun agak lemah, infrastruktur transportasi berpengaruh signifikan namun sangat lemah, dan pertumbuhan teknologi transportasi berpengaruh signifikan namun agak lemah.
\end{abstract}

Kata Kunci: Pembangunan Ruas Jalan, Pembangunan Jembatan, Perekonomian Masyarakat

Abstract. The purpose of this study was to determine the effect of the construction of Cenrana - Labotto roads and bridges on the economic development of the community in Cenrana District. Analyzed using multiple linear regression methods assisted with SPSS 22.0 software to determine the effect of population growth factors, trade growth, transportation infrastructure, and growth of transportation technology on improving the community's economy. The results of the analysis concluded that the factors that significantly influence the Cenrana-Labotto roads and bridges on the improvement of the economy of the Cenrana Subdistrict community are the changes in the economic structure of the community, increasing land prices, as well as population growth which has a significant and strong influence, trade growth has a significant effect but rather weak, transportation infrastructure has a significant but very weak effect, and the growth of transportation technology has a significant but rather weak effect.

Keywords: Roads Construction, Bridges Construction, Community Economy 


\section{PENDAHULUAN}

Pembangunan infrastruktur wilayah mempunyai peranan yang sangat vital dalam pemenuhan hak dasar rakyat, karena infrastruktur merupakan katalis pembangunan. Ketersediaan infrastruktur pada suatu wilayah terutama infrastruktur transportasi, dapat memberikan pengaruh pada peningkatan akses masyarakat terhadap sumberdaya sehingga meningkatkan produktivitas sumberdaya tersebut yang pada akhirnya mendorong pertumbuhan ekonomi dan pembangunan wilayah.

Menurut Grigg (1988), infrastruktur merupakan sistem fisik yang menyediakan transportasi, pengairan, drainase, bangunan gedung, dan fasilitas publik lainnya, yang dibutuhkan untuk memenuhi kebutuhan dasar manusia baik kebutuhan sosial maupun kebutuhan ekonomi. Dalam hal ini, hal-hal yang terkait dengan infrastruktur tidak dapat dipisahkan satu sama lainnya. Sistem lingkungan dapat terhubung karena adanya infrastruktur yang menopang antara sistem sosial dan sistem ekonomi. Ketersediaan infrastruktur memberikan dampak terhadap sistem sosial dan sistem ekonomi yang ada di masyarakat. Maka infrastruktur perlu dipahami sebagai dasar-dasar dalam mengambil kebijakan (Kodoatie, 2005).

Pembangunan infrastruktur transportasi memperlancar arus distribusi barang dan jasa. Secara ekonomi makro, ketersediaan pelayanan infrastruktur akan mempengaruhi tingkat produktivitas marginal modal swasta, sedangkan secara ekonomi mikro, infrastruktur berpengaruh terhadap pengurangan biaya produksi. Infrastruktur juga berpengaruh penting bagi peningkatan kualitas hidup dan kesejahteraan manusia, yang meliputi peningkatan nilai konsumsi, peningkatan produktivitas tenaga kerja dan akses kepada lapangan kerja, serta peningkatan kemakmuran nyata dan terwujudnya stabilitas ekonomi makro, yaitu keberlanjutan fiskal, berkembangnya pasar kredit, dan pengaruhnya terhadap pasar tenaga kerja. Dari sisi tenaga kerja, pembangunan infrastruktur menciptakan peluang usaha dan menampung angkatan kerja sangat besar dan berpotensi untuk memberikan multiplier effect terhadap perekonomian lokal dan perekonomian kawasan.

Infrastruktur sebagai unsur bagian sistem transportasi diharapkan dapat menciptakan dan meningkatkan pertumbuhan ekonomi. Pertumbuhan ekonomi yang tinggi tidak mungkin dicapai apabila tidak ada ketersediaan infrastruktur transportasi yang memadai. Secara tidak langsung, keberadaan infrastruktur transportasi akan mendukung produktivitas sektor ekonomi lainnya sehingga mendorong pertumbuhan ekonomi dan peningkatan kondisi sosial-budaya kehidupan masyarakat melalui efek berganda. Sedangkan secara langsung terkait sektor konstruksi, infrastruktur juga akan menciptakan kesempatan kerja dan usaha. Oleh karena itu, keberadaan infrastruktur dapat mendorong terciptanya stabilitas berbagai aspek dalam masyarakat guna menunjang laju pembangunan nasional.

Terdapat beberapa penelitian yang menyatakan bahwa pembangunan infrastruktur memiliki beberapa dampak positif dan negative (Ananda dkk., 2012; Hakim, 2010; Iek, 2011; Sari, 2009; Hidayat, 2012). Infrastruktur transportasi berupa jaringan jalan berperan penting dalam pembangunan wilayah tertinggal. Adanya infrastruktur jalan yang terhubung ke wilayah-wilayah pelosok memberikan dampak terhadap pertumbuhan ekonomi dan sosial pada wilayah tersebut. Seperti halnya pembangunan ruas jalan dan jembatan CenranaLabotto, khususnya pembangunan jembatan Sungai Walannae yang dikerjakan pada tahun 2012 memiliki peran yang sangat strategis khususnya di Kecamatan Cenrana, sehingga dapat meningkatkan kegiatan ekonomi, distribusi barang dan jasa pada daerah tersebut.

Pergerakan jalur transportasi yang terhambat membuat pembangunan Jembatan Sungai Walannae dinilai penting sebagai pembuka awal antar desa-desa di Kecamatan Cenrana. Ruas jalan Cenrana-Labotto merupakan akses jalan transportasi yang menghubungkan antar desa di Kecamatan Cenrana dan merupakan akses alternative menuju Kabupaten Wajo, namun ruas jalan tersebut dipisahkan oleh Sungai Walannae dengan lebar sungai $\pm 120 \mathrm{~m}$, yang sebelum dibangunnya jembatan sungai Walannae masyarakat menggunakan transportasi laut berupa rakit untuk mobilisasi barang dan penduduk. Dengan dibangunnya jembatan Sungai Walannae yang menghubungkan antar desa di Kecamatan Cenrana melalui jalan darat diharapkan ketimpangan sosial dan ekonomi dapat direduksi, sehingga arus transportasi yang cepat dan efektif akan berpengaruh dalam perkembangan ekonomi di wilayah tersebut.

Berdasarkan teori infrasturktur yang telah dikemukakan, harapannya pembangunan ruas jalan dan jembatan CenranaLabotto, seharusnya dapat memperlancar sistem transportasi dan diharapkan dapat menciptakan dan meningkatkan pertumbuhan ekonomi dan memberikan dampak positif terhadap kedua daerah terhubung berupa perkembangan sosial ekonomi yang signifikan. Untuk mengetahui tingkat perkembangan wilayah tersebut, maka perlu dilakukan analisis ekonomi agar kita mengetahui kondisi ekonomi masyarakat Kecamatan Cenrana setelah dibangunnya infrastruktur jembatan Sungai Walanae yang telah beroperasi sejak tahun 2012 hingga sekarang. Analisis tersebut juga bertujuan untuk mengetahui seberapa besar ruas jalan dan jembatan tersebut mempengaruhi kehidupan masyarakat dan kondisi ekonomi Kecamatan Cenrana Kabupaten Bone. Berdasarkan latar belakang diatas, maka tujuan yang hendak dicapai dalam penelitian ini adalah Mengetahui pengaruh pembangunan ruas jalan dan jembatan Cenrana-Labotto terhadap perkembangan perekonomian masyarakat di Kecamatan Cenrana.

\section{METODE PENELITIAN}

Penelitian ini merupakan penelitian kuantitatif (Quantitative Approach). Penelitian kuantitatif merupakan jenis penelitian dengan menggunakan data-data tabulasi, data angka sebagai bahan pembanding maupun bahan rujukan dalam menganalisis secara deskriptif. Metode analisis deskriptif merupakan suatu metode analisis yang sederhana dapat digunakan untuk menggambarkan kondisi suatu observasi dengan menyajikan dalam bentuk tabel, grafik maupun narasi dengan 
tujuan untuk memudahkan pembaca dalam menafsirkan hasil observasi.

Penelitian ini berlokasi di Kecamatan Cenrana Kabupaten Bone Provinsi Sulawesi Selatan khususnya di Kelurahan Cenrana, Desa Awang Cenrana, Desa Cakkeware dan Desa Labotto yang dimana sebelum dibangunnya infrastruktur jembatan Sungai Walannae masyarakat di desa tersebut menggunakan rakit sebagai transportasi menuju pusat pelayanan. Pemilihan variabel yang digunakan untuk menganalisis Pengaruh Pembangunan Ruas Jalan dan Jembatan Cenrana - Labotto Terhadap Perekonomian Masyarakat dapat dilihat pada Tabel 1 berikut ini:

Tabel 1. Variable Penelitian

\begin{tabular}{|c|c|c|}
\hline No & $\begin{array}{c}\text { Variabel } \\
\text { penelitian }\end{array}$ & Indikator \\
\hline 1 & Penduduk & $\begin{array}{ll}\text { - } & \text { Urbanisasi } \\
\text { - } & \text { Pekerjaan } \\
\text { - } & \text { Pendidikan terakhir } \\
\text { - } & \text { Penghasilan }\end{array}$ \\
\hline 2 & Perdagangan & $\begin{array}{ll}\text { - } & \text { Bentuk usaha } \\
\text { - } & \text { Lama usaha } \\
\text { - } & \text { Modal usaha } \\
\end{array}$ \\
\hline 3 & $\begin{array}{l}\text { Infrastuktur } \\
\text { Transportasi }\end{array}$ & $\begin{array}{ll}\text { - } & \text { Seberapa sering melintasi } \\
\text { - } & \text { Tujuan melintas } \\
\text { - } & \text { Biaya yang dikeluarkan } \\
\end{array}$ \\
\hline 4 & $\begin{array}{l}\text { Teknologi } \\
\text { Transportasi }\end{array}$ & $\begin{array}{l}\text { Teknologi terbaru setelah dan } \\
\text { sebelum adanya jembatan Sungai } \\
\text { Walannae }\end{array}$ \\
\hline
\end{tabular}

Sumber : Hasil Pengolahan, 2018

Sesuai dengan judul penelitian ini, maka yang menjdi populasi adalah seluruh penduduk yang masuk dalam batasan wilayah penelitian yakni di Kecamatan Cenrana Kabupaten Bone Provinsi Sulawesi Selatan khususnya di Kelurahan Cenrana, Desa Awang Cenrana, Desa Cakkeware dan Desa Labotto. Dalam pengambilan sampel dari populasi Malhotra (dalam Umar Husein, 2003:45) menyebutkan bahwa untuk penelitian deskriptif dan kuantitatif, jumlah sampel yang dibutuhkan adalah 100 unit. Dengan mengikuti pedoman ini maka penelitian menggunakan jumlah sampel sebanyak 100 responden.

Metode sampel yang digunakan adalah non probability sampling melalui teknik kuota sampling. Kuota sampling adalah teknik untuk menentukan sampel dari populasi yang mempunyai ciri-ciri tertentu sampai jumlah (kuota) yang diinginkan terpenuhi. Atas berbagai pertimbangan peneliti, maka karakeristik sampel yang dipilih adalah penduduk dari ketiga lokasi penelitian yakni terdiri dari masyarakat Keca-matan Cenrana dan masyarakat penguna ruas jalan dan jembatan Cenrana-Labotto.

Jenis penelitian ini berdasarkan rumusan masalah serta tjuan penelitian yaitu sifatnya deskriptif kuantitatif atau penelitian terapan yang di dalamnya mencakup penelitian survey. Penelitian kuantitatif merupakan jenis penelitian dengan menggunakan data-data tabulasi, data angka sebagai bahan pembanding maupun bahan rujukan dalam menganalisis secara deskriptif.

Dalam penelitian ini terdapat dua metode analisis yang dilakukan untuk menjawab rumusan masalah tentang bagaimana pengaruh pembangunan ruas jalan dan jembatan Cenrana-Labotto terhadap perkembangan perekonomian masyarakat di Kecamatan Cenrana, yakni:

a. Analisis Deskriptif Kuantitatif

Metode analisis deskriptif kuantitatif adalah metode analisis yang digunakan dengan cara mengolah dan menginterprestasikan data yang berbentuk angka dengan perhitungan yang bersifat matematis. dan

b. Analisis Regresi Berganda

Metode analisis regresi berganda dengan alat bantu SPSS 22 yang bertujuan untuk mengetahui pengaruh pembangunan ruas jalan dan jembatan Cenrana-Labotto terhadap perkembangan perekonomian masyarakat di Kecamatan Cenrana Kabupaten Bone. Rumus Regresi Berganda adalah:

$$
\mathbf{Y}=\boldsymbol{\alpha}+\boldsymbol{\beta} 1 \mathbf{X} 1+\boldsymbol{\beta} 2 \times 2
$$

Dimana:

$\alpha=$ Nilai Konstanta

$\beta=$ Nilai Regres

$X=$ nilai Variabel bebas

$Y=$ nilai variable terikat

Variable yang digunakan pada analisis ini terbagi atas 2 jenis, yakni variable terikat dan bebas. Untuk lebih jelasnya adalah sebagai berikut :

a. Variabel terikat (dependent variable) adalah $=\mathrm{Y}$

$\mathrm{Y}=$ Kesejahteraan Masyarakat

b. Variabel bebas (Independent variable) adalah $=\mathrm{X}$, yang terdiri dari:

$\mathrm{X}_{1}=$ Penduduk

$\mathrm{X}_{2}=$ Perdagangan

$\mathrm{X}_{3}=$ Transportasi

$\mathrm{X}_{4}=$ Teknologi

\section{HASIL DAN PEMBAHASAN}

Analisis dengan metode regresi berganda ini dilakukan untuk mengukur perubahan penggunaan lahan dengan menggunakan empat variabel bebas yaitu variabel pertumbuhan penduduk (X1) dengan inikator adalah urbanisasi, pekerjaan, pendidikan terakhir, dan penghasilan. Variabel pertumbuhan perdagangan (X2) dengan inikator adalah bentuk usaha, lama usaha, dan modal usaha. Variabel infrastruktur transportasi (X3) dengan indikator adalah seberapa sering melintasi, tujuan melintas, dan biaya yang dikeluarkan. Variabel pertumbuhan teknologi transportasi (X4) dengan inikator adalah teknologi terbarukan setelah adanya jembatan Sungai Walannae. Hasil dari persamaan regresi dapat dilihat pada Tabel 2 . 
Tabel 2. Hasil Analisis Regresi Ganda (Coefficients ${ }^{a}$ ) Menggunakan SPSS 22.0 Tahun 2019

\begin{tabular}{|c|c|c|c|c|c|c|c|c|}
\hline \multirow{2}{*}{ Model } & \multicolumn{2}{|c|}{$\begin{array}{c}\text { Unstandardized } \\
\text { Coefficients }\end{array}$} & \multirow{2}{*}{$\begin{array}{c}\begin{array}{c}\text { Standardized } \\
\text { Coefficients }\end{array} \\
\text { Beta }\end{array}$} & \multirow{2}{*}{$t$} & \multirow{2}{*}{ Sig. } & \multicolumn{3}{|c|}{ Correlations } \\
\hline & $B$ & $\begin{array}{c}\text { Std. } \\
\text { Error }\end{array}$ & & & & $\begin{array}{l}\text { Zero- } \\
\text { order }\end{array}$ & Partial & Part \\
\hline (Constant) & .970 & .775 & & 1.252 & .214 & & & \\
\hline Pertumbuhan Penduduk (X1) & .176 & .019 & .604 & 9.184 & .000 & .586 & .686 & .601 \\
\hline Pertumbuhan Perdagangan (X2) & .306 & .053 & .379 & 5.723 & .000 & .348 & .506 & .375 \\
\hline Infrastruktur Transportasi (X3) & .237 & .123 & .126 & 1.919 & .058 & .074 & .193 & .126 \\
\hline $\begin{array}{l}\text { Pertumbuhan Teknologi } \\
\text { Transportasi (X4) }\end{array}$ & .180 & .032 & .372 & 5.607 & .000 & .264 & .499 & .367 \\
\hline
\end{tabular}

Sumber: Hasil Pengolahan, 2018

Berdasarkan nilai pada kolom (Unstandardized Coefficients-B) diatas, maka hasil persamaan regresi di Tabel 2 dapat dijelaskan sebagai berikut:

a. Konstanta sebesar 0,970 ; artinya jika pertumbuhan penduduk $\left(\mathrm{X}_{1}\right)$, pertumbuhan perdagangan $\left(\mathrm{X}_{2}\right)$, infrastruktur transportasi $\left(\mathrm{X}_{3}\right)$, dan pertumbuhan teknologi transportasi $\left(\mathrm{X}_{4}\right)$ nilainya tetap atau sama dengan nol, maka besarnya peningkatan perekonomian masyarakat $(\mathrm{Y})$ nilainya adalah 0,970 .

b. Koefisien regresi variabel pertumbuhan penduduk $\left(\mathrm{X}_{1}\right)$ sebesar 0,176; artinya jika variabel independen lain nilainya tetap dan pertumbuhan penduduk mengalami kenaikan $1 \%$, maka perekonomian masyarakat (Y) akan mengalami peningkatan sebesar 0,970. Koefisien bernilai positif artinya terjadi hubungan positif antara pertumbuhan penduduk dengan perekonomian masyarakat, semakin naik pertumbuhan penduduk maka semakin meningkat perekonomian masyarakat.

c. Koefisien regresi variabel pertumbuhan perdagangan $\left(\mathrm{X}_{2}\right)$ sebesar 0,306; artinya jika variabel independen lain nilainya tetap dan pertumbuhan perdagangan mengalami kenaikan 1\%, maka perekonomian masyarakat (Y) akan mengalami peningkatan sebesar 0,970 . Koefisien bernilai positif artinya terjadi hubungan positif antara pertumbuhan perdagangan dengan perekonomian masyarakat, semakin naik pertumbuhan perdagangan maka semakin meningkat perekonomian masyarakat.

d. Koefisien regresi variabel infrastruktur transportasi $\left(\mathrm{X}_{3}\right)$ sebesar 0,237; artinya jika variabel independen lain nilainya tetap dan infrastruktur transportasi mengalami kenaikan 1\%, maka perekonomian masyarakat (Y) akan mengalami penurunan sebesar 0,970 . Koefisien bernilai positif artinya terjadi hubungan positif antara infrastruktur transportasi dengan perekonomian masyarakat, semakin naik infrastruktur transportasi maka semakin meningkat perekonomian masyarakat.

Setelah melakukan uji regresi, maka uji t (uji parsial) juga dilakukan untuk mengetahui apakah variabel pertumbuhan penduduk $\left(\mathrm{X}_{1}\right)$, variabel pertumbuhan perdagangan $\left(\mathrm{X}_{2}\right)$, variabel infrastruktur transportasi $\left(\mathrm{X}_{3}\right)$, dan variabel pertumbuhan teknologi transportasi $\left(\mathrm{X}_{4}\right)$ secara parsial (sendirisendiri) berpengaruh secara signifikan terhadap variabel kri- teria $(\mathrm{Y})$. Signifikan berarti hubungan yang terjadi dapat berlaku untuk populasi (dapat digeneralisasikan), hasil $t_{\text {tabel }}$ setiap variabel bebas terhadap variabel terikat pada penelitian ini ialah:

a. Faktor Pertumbuhan Penduduk $\left(\mathrm{X}_{1}\right)$ dengan $\mathrm{t}_{\text {hitung }}>\mathrm{t}_{\text {tabel }}$ $(9,184>1,291)$, maka pertumbuhan penduduk berpengaruh signifikan terhadap peningkatan perekonomian masyarakat di Kecamatan Cenrana.

b. Faktor Pertumbuhan Perdagangan $\left(X_{2}\right)$ dengan $t_{\text {hitung }}>t_{\text {tabel }}$ $(5,723>1,291)$, maka pertumbuhan perdagangan berpengaruh signifikan terhadap peningkatan perekonomian masyarakat di Kecamatan Cenrana.

c. Faktor Infrastruktur Transportasi $\left(\mathrm{X}_{3}\right)$ dengan $t_{\text {hitung }}>\mathrm{t}_{\text {tabel }}$ $(1,919>1,291)$, maka infrastruktur transportasi berpengaruh signifikan terhadap peningkatan perekonomian masyarakat di Kecamatan Cenrana.

d. Faktor Pertumbuhan Teknologi Transportasi $\left(\mathrm{X}_{4}\right)$ dengan $t_{\text {hitung }}>t_{\text {tabel }}(5,607>1,291)$, maka pertumbuhan teknologi transportasi berpengaruh signifikan terhadap peningkatan perekonomian masyarakat di Kecamatan Cenrana.

Koefisien korelasi dalam regresi linear berganda digunakan untuk mengetahui hubungan antara variabel prediktor pertumbuhan penduduk $\left(\mathrm{X}_{1}\right)$, pertumbuhan perdagangan $\left(\mathrm{X}_{2}\right)$, infrastruktur transportasi $\left(\mathrm{X}_{3}\right)$, dan pertumbuhan teknologi transportasi $\left(\mathrm{X}_{4}\right)$ secara parsial (sendiri-sendiri) berpengaruh terhadap variabel kriterium $(\mathrm{Y})$. Koefisien ini menunjukkan seberapa besar hubungan yang terjadi antara variabel prediktor $\left(\mathrm{X}_{1}, \mathrm{X}_{2}, \mathrm{X}_{3}, \mathrm{X}_{4}\right)$ secara sendiri-sendiri terhadap variabel kriterium $(\mathrm{Y})$. Nilai $\mathrm{R}$ berkisar antara 0 sampai 1 , nilai semakin mendekati 1 berarti hubungan yang terjadi semakin kuat, sebaliknya nilai semakin mendekati 0 maka hubungan yang terjadi semakin lemah.

a. Faktor Pertumbuhan Penduduk $\left(\mathrm{X}_{1}\right)$

Dari hasil analisis koefisien regresi pada Tabel 2, dalam kolom (Correlations-Partial) diperoleh angka $\mathrm{R}$ untuk variabel pertumbuhan penduduk sebesar 0,686. Nilai tersebut menunjukkan bahwa terjadi hubungan yang cukup kuat antara pertumbuhan penduduk $\left(\mathrm{X}_{1}\right)$ terhadap peningkatan perekonomian masyarakat (Y). Angka positif (searah) mengartikan bahwa jika pertumbuhan penduduk meningkat maka perekonomian masyarakat juga akan mengalami peningkatan. 
b. Faktor Pertumbuhan Perdagangan $\left(\mathrm{X}_{2}\right)$

Dari hasil analisis koefisien regresi pada Tabel 2, dalam kolom (Correlations-Partial) diperoleh angka $\mathrm{R}$ untuk variabel pertumbuhan penduduk sebesar 0,506. Nilai terse-but menunjukkan bahwa terjadi hubungan yang agak lemah antara pertumbuhan perdagangan $\left(\mathrm{X}_{2}\right)$ terhadap pening-katan perekonomian masyarakat (Y). Angka positif (searah) mengartikan bahwa jika pertumbuhan perdagangan me-ningkat maka perekonomian masyarakat juga akan menga-lami peningkatan.

c. Faktor Infrastruktur Transportasi $\left(\mathrm{X}_{3}\right)$

Dari hasil analisis koefisien regresi pada Tabel 2, dalam kolom (Correlations-Partial) diperoleh angka $\mathrm{R}$ untuk variabel infrastruktur transportasi sebesar 0,193. Nilai tersebut menunjukkan bahwa terjadi hubungan yang sangat lemah antara infrastruktur transportasi $\left(\mathrm{X}_{3}\right)$ terhadap peningkatan perekonomian masyarakat (Y). Angka positif (searah) mengartikan bahwa jika infrastruktur transportasi meningkat maka perekonomian masyarakat juga akan mengalami peningkatan.

d. Faktor Pertumbuhan Teknologi Transportasi $\left(\mathrm{X}_{4}\right)$

Dari hasil analisis koefisien regresi pada Tabel 2, dalam kolom (Correlations-Partial) diperoleh angka $\mathrm{R}$ untuk variabel pertumbuhan teknologi transportasi sebesar 0,499 . Nilai tersebut menunjukkan bahwa terjadi hubungan yang agak lemah antara pertumbuhan teknologi transportasi $\left(\mathrm{X}_{4}\right)$ terhadap peningkatan perekonomian masyarakat (Y). Ang-ka positif (searah) mengartikan bahwa jika partumbuhan teknologi transportasi meningkat maka perekonomian ma-syarakat juga akan mengalami peningkatan.

Berdasarkan pertimbangan dari berbagai faktor yang telah disebutkan para ahli diatas, maka dirumuskanlah empat faktor yang dianggap mewakili dalam mengukur pengaruh signifikan dari terhubungnya ruas jalan dan jembatan Cenrana-Labotto terhadap perekonomian masyarakat Kecamatan Cenrana. Keempat faktor yang kemudian menjadi variabel tersebut antara lain penduduk $\left(\mathrm{X}_{1}\right)$ yang diukur dengan (urbanisasi, perekjaan, pendidikan terakhir, dan penghasilan), perdagangan $\left(\mathrm{X}_{2}\right)$ yang diukur dengan (bentuk usaha, lama usaha, dan modal usaha), infrastruktur transportasi $\left(\mathrm{X}_{3}\right)$ yang diukur dengan (seberapa sering melintas, tujuan melintas, dan biaya yang dikeluarkan), dan teknologi transportasi $\left(\mathrm{X}_{4}\right)$ yang diukur dengan (teknologi terbarukan).

Keempat faktor diatas diuraikan dalam daftar pertanyaan penelitian (kuesioner) dan disebarkan ke sebanyak 100 responden yang tersebar pada empat empat desa/kelurahan sepanjang ruas jalan dan jembatan Cenrana-Labotto, yakni Kelurahan Cenrana, Desa Awang Cenrana, Desa Cakkeware, dan Desa Labotto. Dengan diproses menggunakan analisi regresi linear berganda seperti yang telah dilakukan pada pembahasan sebelumnya, keempat variabel yang diukur tersebut dinyatakan memiliki pengaruh terhadap perekonomian masyarakat Kecamatan Cenrana.

Faktor pertumbuhan penduduk yang diukur dengan urbanisasi, perekjaan, pendidikan terakhir, dan penghasilan ternyata memiliki pengaruh signifikan dan cukup kuat terhadap me- ningkatnya perekonomian masyarakat Kecamatan Cenrana khususnya di sepanjang ruas jalan dan jembatan CenranaLabotto. Hal ini sesuai dengan hasil wawancara terbuka terhadap sebagian besar responden, mereka menjelaskan bahwa pertumbuhan penduduk sebagai dampak dari pembangunan ruas jalan dan jembatan Cenrana-Labotto berpengaruh terhadap peningkatan perekonomian masyarakat. Adanya urbanisasi karena terbukanya akses jalan dan jembatan, mudahnya masyarakat mendapatkan pekerjaan karena terbukanya akses jalan dan jembatan, peningkatan tingkat pendidikan karena terbukanya akses jalan dan jembatan, serta meningkatnya penghasilan karena terbukanya akses jalan dan jembatan, kesemua itu berpengaruh cukup kuat terhadap meningkatnya perkonomian masyarakat pada wilayah tersebut.

Faktor kedua yang berpengaruh signifikan namun agak lemah terhadap meningkatnya perekonomian masyarakat Kecamatan Cenrana khususnya di sepanjang ruas jalan dan jembatan Cenrana-Labotto adalah pertumbuhan perdagangan yang diukur dengan bentuk usaha, lama usaha, dan modal usaha. Hal ini sesuai dengan hasil wawancara terbuka terhadap sebagian besar responden, mereka menjelaskan bahwa pertumbuhan perdagangan sebagai dampak dari pembangunan ruas jalan dan jembatan Cenrana-Labotto berpengaruh terhadap peningkatan perekonomian masyarakat. Beragamnya bentuk usaha karena terbukanya akses jalan dan jembatan, usaha yang bertahan lama karena terbukanya akses jalan dan jembatan, serta meningkatnya modal usaha karena terbukanya akses jalan dan jembatan, semua hal tersebut berpengaruh agak lemah terhadap meningkatnya perkonomian masyarakat pada wilayah tersebut.

Faktor ketiga yang berpengaruh signifikan namun sangat lemah terhadap meningkatnya perekonomian masyarakat Kecamatan Cenrana khususnya di sepanjang ruas jalan dan jembatan Cenrana-Labotto adalah infrastruktur transportasi yang diukur dengan seberapa sering melintas, tujuan melintas, dan biaya yang dikeluarkan. Hal ini sesuai dengan hasil wawancara terbuka terhadap sebagian besar responden, mereka menjelaskan bahwa infrastruktur transportasi sebagai dampak dari pembangunan ruas jalan dan jembatan CenranaLabotto berpengaruh terhadap peningkatan perekonomian masyarakat. Seringnya masyarakat melintas karena terbukanya akses jalan dan jembatan, beragamnya tujuan masyarakat untuk melintas karena terbukanya akses jalan dan jembatan, serta berkurangnya biaya yang dikeluarkan karena terbukanya akses jalan dan jembatan, semua hal tersebut berpengaruh sangat lemah terhadap meningkatnya perkonomian masyarakat pada wilayah tersebut.

Faktor keempat yang berpengaruh signifikan namun agak lemah terhadap meningkatnya perekonomian masyarakat Kecamatan Cenrana khususnya di sepanjang ruas jalan dan jembatan Cenrana-Labotto adalah pertumbuhan teknologi transportasi yang diukur dengan masuknya teknologi terbarukan. Hal ini sesuai dengan hasil wawancara terbuka terhadap sebagian besar responden, mereka menjelaskan bahwa meningkatnya teknologi transportasi sebagai dampak dari pembangunan ruas jalan dan jembatan Cenrana-Labotto berpengaruh terhadap peningkatan perekonomian masya- 
rakat. Adanya teknologi terbarukan seperti meningkatnya pemilik kendaraan, alat teknologi pertanian dan lainnya karena terbukanya akses jalan dan jembatan. Hal tersebut berpengaruh cukup lemah terhadap meningkatnya perkonomian masyarakat pada wilayah tersebut.

\section{KESIMPULAN}

Pengaruh pembanguna ruas jalan dan jembatan CenranaLabotto terhadap perekonomian masyarakat Kecamatan Cenrana berpengaruh signifikan, dimana faktor pertumbuhan penduduk yang diukur dengan urbanisasi, perekjaan, pendidikan terakhir, dan penghasilan ternyata memiliki pengaruh signifikan dan cukup kuat Faktor pertumbuhan perdagangan yang diukur dengan bentuk usaha, lama usaha, dan modal usaha berpengaruh signifikan namun agak lemah. Faktor infrastruktur transportasi yang diukur dengan seberapa sering melintas, tujuan melintas, dan biaya yang dikeluarkan berpengaruh signifikan namun sangat lemah. Faktor pertumbuhan teknologi transportasi yang diukur dengan masuknya teknologi terbarukan berpengaruh signifikan namun agak lemah

\section{DAFTAR PUSATAKA}

Ananda, Tri Dharma Yanti. (2011). Dampak Kebijakan Pembangunan Jembatan Suramadu Terhadap Sosial Ekonomi Masyarakat Dalam Pengembangan Wilayah Jembatan Suramadu (Studi Di Desa Sukolilo Barat Kecamatan Labang Kabupaten Bangkalan). Jurnal Ekonomi.
Grigg, N. (1988). Infrastructure Engineering and Management. John Wiley \& Sons.

Kodoatie, Robert J. (2005). Pengantar manajemen infrastruktur. Pustaka Pelajar: Yogyakarta

M. Andri Hakim. (2010). Sosial \& Economic Mapping Sisi Madura Dan Sisi Surabaya Dalam Mendukung Tata Ruang Suramadu. Jurnal Ekonomi.

Mesak Iek.Analisis. (2013). Dampak Pembangunan Jalan Terhadap Pertumbuhan Usaha Ekonomi Rakyat di Pedalaman May Brat Provinsi Papua Barat (Studi Kasus di Distrik Ayamaru, Aitinyo dan Aifat). Jurnal Ekonomi.

Perwita sari. (2009). Pengaruh Pembangunan Infrastruktur Terhadap Pertumbuhan Ekonomi 25 Kabupaten Tertinggal Kawasan Timur Indonesia. Skripsi IPB.

Robinson. (2005). Perencanaan Pembangunan Wilayah. Jakarta: Bumi Aksara.

Taringan Robinson. (2005). Ekonomi Regional. Jakarta: Bumi Aksara. Taringan

Taufik Hidayat. (2010). Dampak Pembangunan Jembatan Suramadu Terhadap Masyarakat Madura: Tinjauan Dari Sisi Perekonomian Dan Kesejahteraan. Jurnal Ekonomi. 